\title{
EFFECT OF LEARNING USING MATHEMATICA SOFTWARE TOWARD MATHEMATICAL ABSTRACTION ABILITY, MOTIVATION, AND INDEPENDENCE OF STUDENTS IN ANALYTIC GEOMETRY
}

\author{
Yanuar Hery Murtianto ${ }^{1}$, Sutrisno ${ }^{* 2}$, Nizaruddin ${ }^{3}$, Muhtarom ${ }^{4}$ \\ ${ }_{1,2,3,4}$ Universitas PGRI Semarang
}

\section{Article Info \\ Article history: \\ Received April 30, 2019 \\ Revised Sept 25, 2019 \\ Accepted Sept 26, 2019}

\section{Keywords:}

Analytic Geometry,

Learning Independence,

Learning Motivation,

Mathematica,

Mathematical Abstraction

\begin{abstract}
Rapid development of technology for the past two decades has greatly influenced mathematic learning system. Mathematica software is one of the most advanced technology that helps learn math especially in Geometry. Therefore this research aims at investigating the effectiveness of analytic geometry learning by using Mathematica software on the mathematical abstraction ability, motivation, and independence of students. This research is a quantitative research with quasi-experimental method. The independent variable is learning media, meanwhile the dependent variables are students' mathematical abstraction ability, motivation, and independence in learning. The population in this research was the third semester students of mathematics education program and the sample was selected using cluster random sampling. The samples of this research consisted of two distinct classes, with one class as the experimental class was treated using Mathematica software and the other is the control class was treated without using it. Data analyzed using multivariate, particularly Hotelling's $\mathrm{T}^{2}$ test. The research findings indicated that learning using Mathematica software resulted in better mathematical abstraction ability, motivation, and independence of students, than that conventional learning in analytic geometry subject.
\end{abstract}

Copyright @ 2019 IKIP Siliwangi. All rights reserved.

\section{Corresponding Author:}

Sutrisno,

Departement of Mathematics Education,

Universitas PGRI Semarang,

Jl.Sidodadi Timur No. 24, Semarang, Indonesia.

Email: sutrisnojr@upgris.ac.id

\section{How to Cite:}

Murtianto, Y. H., Sutrisno, S., Nizaruddin, N., \& Muhtarom, M. (2019). Effect of learning using Mathematica software toward mathematical abstraction ability, motivation, and independence of students in analytic geometry. Infinity, 8(2), 219-228.

\section{INTRODUCTION}

Rapid development of technology for the past two decades has greatly influenced mathematic learning system. Higher order thinking skills ability a person is a requirement the main one is able to compete in this $21^{\text {st }}$ century and mathematics that has an important role in the development of high-order thinking skills. So that technological and mathematical collaboration is needed in answering this challenge. Mathematics pre-teacher students are part of a system which is directly influenced by the development of 
technology. On the other hand the emphasis was on learning mathematics must be in context since learning should be involve the mental processes of students, should be fun, encourage students, and give students the opportunity to construct their learning experience, so that learning become meaningful (Nizaruddin, Muhtarom \& Sugiyanti, 2017). Furthermore, motivation provides a very important role (Rachvelishvili, 2017), in addition to the use of technology in learning mathematics. As it was delivered some researchers have conducted studies that emphasis the view that the success of students' problem-solving is an important factor in understanding the beliefs of mathematics; students' beliefs toward solving the problem also depend on the motivation of the belief in mathematic (Muhtarom, Juniati \& Siswono, 2017a; 2017b).

One of the technology advances in mathematics learning system is the choice variances of mathematics software. The variances are divided into two important parts; dynamic geometry system and computer algebraic system (Malinova, 2010). Among the mathematical software are Maple, Mathematica, Geometer Sketchpad, Matlab, and Geogebra. A great number of software that can be used by mathematics pre-service teachers in learning requires them to skilfully utilize software they plan to choose (Listyani, 2006).

Taking account to this phenomenon, it is necessary that the students of mathematics education program are provided with computer software utilization skill in order to meet the demands of the workplace. One of mathematic software that can be applied by the students is Mathematica software. Mathematica is symbol visualization and algebraic manipulation based computer software that was developed by Stephen Wolfram. It is one of today's most up-to-date software and this is confirmed by several previous studies by Gocheva (2009), Malinova (2010) and Vosler (2009) which reveal that Mathematica software is effective in mathematics learning at university level which investigates concept and finds its connection to other mathematical concepts or its implementation with technology. A more specific research was carried out by Kapustina, Popyrin, \& Savina (2015) indicating that visualization concepts of analytic geometry would be easier when presented using this software.

The importance of Mathematica software in Analytic Geometry learning is undeniable. This is obvious from the previous studies, two of which were the research Sunandar, Murtianto \& Sutrisno (2015) on the development of Analytic Geometry teaching materials using Mathematica software in developing students' representation, and the research on improving achievement and differential calculus learning independence of mathematics education program students of Universitas Negeri Yogyakarta using Mathematica software (Listyani, 2006). A number of studies that have been conducted related to software-assisted mathematics learning indicate that the era of modern mathematics learning in the class continues to grow rapidly.

The use of software in mathematics learning in classroom should consider the portion and the conformity level to learning objectives. This is so for it can put an effect on the level of abstraction, motivation, and learning independence of students. This thinkable concept can later be used in more complicated and complex level of thinking. The states can raise first abstraction when an individual focuses on the characteristics of objects observed and then label them through a classification process into several groups on the basis of certain categories. Motivation in mathematics education is important for it provides energy in learning which can be adapted to bridge (Hannula, 2006). Meanwhile, motivation is a natural characteristic of a person that can be explored in line with the needs (Pintrich, 2003). Indeed, motivation cannot be considered directly, but it can be observed from the manifestation of behavior, attitude, and activity of an individual. The general problem is that the average research that has been done previously only emphasizes the 
cognitive aspects of the dependent variable. Research that takes the dependent variable motivation, independence and abstraction ability is usually also carried out separately and not simultaneously. Then the purpose of this study is to find out the impact of learning using mathematica on motivation, abstraction ability and independence simultaneously. Thus, mathematics learning using mathematica software demands certain motivation to change behavior and attitude through a process of learning, and this is expected to put an effect on the students' independence.

\section{METHOD}

\subsection{General Background of Research}

This research applied a quantitative approach with a quasi-experimental, because in this research it is not possible for researchers all relevant variables. Budiyono (2003) stated that research in education is included in quasi-experimental research because educational research often uses intact groups such as classes as experimental groups and classes as groups comparison. This is so for it is impossible for the researcher to control all the relevant variables (Budiyono, 2003). Some research experts suggest that researches in the field of education are considered quasi-experimental researches since educational researches often make use of intact groups such as classes as experimental class was treated using Mathematica software and control class was treated without using them (conventional learning). In this case, randomization is not applied in determining subject assigned to experimental class and control class. The variables in this research were divided into independent and dependent variables. The independent variables were learning media, while the dependent variables were students' mathematical abstraction, motivation, and independence. Multivariate analysis technique, particularly Hotelling's $\mathrm{T}^{2}$ test statistics, was applied for analyzing data since this research only compared two classes (control class and experimental class) and involved three dependent variables, including students' mathematical abstraction, learning motivation and learning independence.

\subsection{Sample of Research}

The population of this research is a group of students attending Analytic Geometry Course on third semester that consist of six class in Mathematics Education Department of Universitas PGRI Semarang in the academic year 2018/2019. The sampling of the research using cluster random sampling. The samples of this research consisted of two distinct classes, with one class as the control class and the other is the experimental class.

\subsection{Instrument and Procedures}

Data collection techniques is used in this research are tests and questionnaires. The test technique is used to measure the ability of mathematical abstraction, the questionnaire is used to measure the students' motivation and student's independence. The mathematical abstraction ability test is used in the form of description consists of two questions, while the questionnaire motivation and student's independence in the form of a closed questionnaire with four answer options (strongly agree, agree, disagree, and strongly disagree) consisting of 30 items of statement. All such instruments was used to obtain preliminary and final ability data. The student's preliminary ability data was used for the balance test (i.e. univariate normality test, multivariate normality test, homogeneity of variance test, homogeneity of covariance matrices test, and Hotelling's $\mathrm{T}^{2}$ test), while the student's final ability data was used as the test of the research hypothesis, as in the balance 
test. The research was conducted from August to December 2018, while the preliminary ability data was collected prior to the research.

\subsection{Data Analysis}

Multivariate analysis technique, particularly Hotelling's $T^{2}$ test statistics, was applied for analyzing data since this research only compared two classes (control class and experimental class) and involved three dependent variables, including students' mathematical abstraction, learning motivation and learning independence. This data analysis technique was used twice, i.e. in balance test for preliminary research data and in hypothesis test for final research data. Balance test was intended to determine that both control and experimental classes were in balance before receiving any treatments. This test was carried out to ensure that any changes after treatment provided were resulted from the treatment. Before conducting this test statistics, it was necessary to perform prerequisite tests, including multivariate normality test and covariance matrix homogeneity test. Mardia test was used to test the data normality, while Box's $M$ was used to test the covariance matrix homogeneity (Rencher, 2002).

\section{RESULTS AND DISCUSSION}

\subsection{Results}

Preliminary data of abilities in this research were data of students' mathematical abstraction ability, motivation and independency in learning analytic geometry subject before experiments were conducted. Data of mathematical abstraction ability were obtained using written test, while data of learning motivation and independence were obtained using questionnaires. The test was carried out using multivariate technique, particularly test statistics of Hotelling's $T^{2}$. Univariate normality test of population obtained in reference to the results of analysis, it was found that both samples constructed test statistics of $D \leq D_{\alpha}$ and therefore not rejected $H_{0}$. This was also supported by the $p$ value $\geq \alpha=0.05$ for all samples. Thus, and the significance level of $5 \%$ for both samples was derived from univariate normally-distributed populations. Furthermore multivariate normality test of population have been showed that both samples constructed test statistics of $b_{1, p} \leq b_{1, p, 1-\alpha, n}$ and $b_{2, p, \alpha / 2, n} \leq b_{2, p} \leq b_{2, p, 1-(\alpha / 2), n}$. That $b_{1, p}$ is the slope coefficient if it is less than $b_{1, p, 1-\alpha, n}$ then it is said to be symmetrical distribution, $b_{2, p}$ is the coefficient of shaking if it is between $b_{2, p, \alpha / 2, n}$ and $b_{2, p, 1-(\alpha / 2), n}$ then the distribution is normal (mesokurtic). This was supported by $p$-value $\geq \alpha=0.05$ for all samples and therefore not rejected $H_{0}$. Therefore, the significance levels of $5 \%$ of both samples were obtained from multivariate normally-distributed populations.

Homogeneity test of population variance demonstrated that all dependent variables appeared to construct test statistics of $F_{1-(\alpha / 2)} \leq F \leq F_{\alpha / 2}$ and therefore not rejected $H_{0}$. This was supported by $p$-value $\geq \alpha=0.05$ for all variables. Hence, with the significance levels of $5 \%$, both populations showed homogenous variances for each dependent variable. Moreover homogeneity test of population covariance matrices indicated Box's $M=5.359$. The value could eventually be interpreted using critical value table of Box's $M$ test in one condition that every cell in factorial design had equal sample size. However, the condition was not fulfilled in this research, and hence Box's $M$ value could not be directly interpreted. For the purpose of interpretation, $F$ approach was employed. For $F \leq F_{\alpha}$ and therefore not rejected $H_{0}$. This was supported by $p$-value $\geq \alpha=0.05$. In conclusion, with $5 \%$ significance level, both populations showed homogenous covariance matrices. 
On the basis of multivariate test using SPSS, Pillai's Trace test resulted in $F=$ 0.214 with $p=0.886$; Wilk's Lambda test resulted in $F=0.214$ with $p=0.886$; Hotelling's Trace test constructed $F=0.214$ with $p=0.886$; and Roy's Largest Root test produced $F=$ 0.214 with $p=0.886$. All the tests resulted in $p \geq \alpha=0.05$ and therefore not rejected $H_{0}$. This research focused more on Hotelling's $T^{2}$ test. The results of analysis revealed that statistical test of $T^{2} \leq T^{2}{ }_{\alpha}$ was constructed $\left(T^{2}=0.670\right.$ and $\left.T_{\alpha}^{2}=6.552\right)$. Statistical test of $F$ $\leq F_{\alpha}$ was also derived $\left(F=0.214\right.$ and $\left.F_{\alpha}=2.816\right)$. This was also supported by $p$-value $\geq \alpha=$ 0.05 and therefore not rejected $H_{0}$. Hence, with $5 \%$ significance level, both populations had equal and balanced early abilities. All parts that had changed after receiving treatments in experimental class were influenced by the treatments provided.

Table 1. Univariate normality test of population

\begin{tabular}{lcccccc}
\hline Data Source & Dependent Variable & $\boldsymbol{n}$ & $\boldsymbol{D}$ & $\boldsymbol{D}_{\boldsymbol{\alpha}}$ & $\boldsymbol{p}$-value & Result \\
\hline Control Class & $\begin{array}{c}\text { Mathematical } \\
\text { abstraction }\end{array}$ & 26 & 0.112 & 0.171 & $0.200^{*}$ & not rejected $H_{0}$ \\
& $\begin{array}{c}\text { Motivation } \\
\text { Class }\end{array}$ & 26 & 0.101 & 0.171 & $0.200^{*}$ & not rejected $H_{0}$ \\
& $\begin{array}{c}\text { Independence } \\
\text { Mathematical } \\
\text { abstraction }\end{array}$ & 26 & 0.110 & 0.171 & $0.200^{*}$ & not rejected $H_{0}$ \\
& $\begin{array}{c}\text { Motivation } \\
\text { Experimental }\end{array}$ & 22 & 0.089 & 0.183 & $0.200^{*}$ & not rejected $H_{0}$ \\
& Independence & 22 & 0.074 & 0.183 & $0.200^{*}$ & not rejected $H_{0}$
\end{tabular}

Research data were data of students' mathematical abstraction ability, motivation, and learning independence which they obtained after experiment. The data were demon and served as dependent variables to test research hypothesis. The research hypothesis test was carried out using multivariate technique, particularly Hotellings $T^{2}$ test statistics. The followings are the statistical discussions of the test analysis results.

The results of analysis demonstrated at Table 1 showed that both samples constructed test statistics of $D \leq D_{\alpha}$ and therefore not rejected $H_{0}$. This was supported by $p$ value $\geq \alpha=0.05$ for all samples. Hence, with the significance level of $5 \%$, both samples were obtained from univariate normally-distributed populations.

Table 2. Multivariat normality test of population of research data

\begin{tabular}{ccccccc}
\hline Data Source & $\boldsymbol{n}$ & \multicolumn{2}{l}{ Test Statistics } & $\boldsymbol{b}_{\boldsymbol{\alpha}}$ & $\boldsymbol{p}$-value & Result \\
\hline Control Class & 26 & $b_{1, p}$ & 0.6769 & 3.780 & 0.9830 & $\begin{array}{c}\text { not } \\
\text { rejected } H_{0}\end{array}$ \\
& & $b_{2, p}$ & 12.0565 & $\begin{array}{l}\text { Lower }=11.440 \\
\text { Upper }=17.420\end{array}$ & 0.1706 & \\
$\begin{array}{c}\text { Experimental } \\
\quad 22\end{array}$ & $b_{1, p}$ & 1.1482 & 4.623 & 0.9374 & not \\
& & $b_{2, p}$ & 11.5547 & $\begin{array}{l}\text { Lower }=11.220 \\
\text { Upper }=17.280\end{array}$ & 0.1402 & rejected $H_{0}$ \\
\hline
\end{tabular}

Table 2 clearly as showed that both samples appeared to construct test statistics of $b_{1, p} \leq b_{1, p, 1-\alpha, n}$ and $b_{2, p, \alpha / 2, n} \leq b_{2, p} \leq b_{2, p, 1-(\alpha / 2), n}$. This was supported by $p$-value $\geq \alpha=0.05$ for 
all samples and therefore not rejected $H_{0}$. Hence, with the significance level of $5 \%$, both samples were obtained from multivariate normally-distributed populations.

Table 3. Homogeneity test of population variance of research data

\begin{tabular}{ccccccc}
\hline $\begin{array}{c}\text { Dependent } \\
\text { Variable }\end{array}$ & Data Source & $\mathbf{s}_{\mathbf{i}}^{2}$ & $\boldsymbol{F}$ & $\boldsymbol{F}_{\boldsymbol{\alpha}}$ & p-value & Result \\
\hline $\begin{array}{c}\text { Mathematical } \\
\text { Abstraction }\end{array}$ & Control Class & 64.135 & 1.0083 & $\begin{array}{l}\text { Lower }=0.4378 \\
\text { Upper }=2.3558\end{array}$ & 0.9942 & $\begin{array}{c}\text { not } \\
\text { rejected } H_{0}\end{array}$ \\
& $\begin{array}{c}\text { Experimental } \\
\text { Class }\end{array}$ & 63.610 & & & & \\
Motivation & Control Class & 63.335 & 1.0235 & $\begin{array}{l}\text { Lower }=0.4245 \\
\text { Upper }=2.2840\end{array}$ & 0.9465 & $\begin{array}{c}\text { not } \\
\text { rejected } H_{0}\end{array}$ \\
& $\begin{array}{c}\text { Experimental } \\
\text { Class }\end{array}$ & 64.824 & & & & \\
Independence & Control Class & 65.433 & 1.0245 & $\begin{array}{l}\text { Lower }=0.4378 \\
\text { Upper }=2.3558\end{array}$ & 0.9642 & not \\
& Experimental \\
Class & 63.870 & & & & rejected $H_{0}$ \\
& & & & & \\
\hline
\end{tabular}

Table 3 indicated that all dependent variables appeared to construct test statistics of $F_{1-(\alpha / 2)} \leq F \leq F_{\alpha / 2}$, and therefore not rejected $H_{0}$. This was also supported by $p$-value $\geq \alpha=$ 0.05 for all variables. Hence, with the significance level of $5 \%$, both populations constructed homogenous variances for each dependent variable. Table 4 clearly as showed that the revealed Box's $M=3.160$. The value could substantively be interpreted with the assistance of critical value table of Box's $M$ test in one condition that each cell in factorial design had equal sample size. However, the condition was not met in this research, and therefore Box's $M$ value could not be interpreted directly. For the purpose of interpretation, $F$ approach was applied. Table 4 indicated that all dependent variables appeared to construct test statistics of $F \leq F_{\alpha}$ and therefore not rejected $H_{0}$. This is proven by $p$-value $\geq$ $\alpha=0.05$. Hence with the significance level of $5 \%$, both populations had homogenous covariance matrices.

Table 4. Homogeneity test of population covariance matrices of research data

\begin{tabular}{|c|c|c|c|c|c|c|c|c|}
\hline Data Source & & $S_{i}$ & & Box's M & $F$ & $\boldsymbol{F}_{a}$ & $\begin{array}{c}p- \\
\text { value }\end{array}$ & Result \\
\hline \multirow{3}{*}{$\begin{array}{c}\text { Control } \\
\text { Class }\end{array}$} & 64,135 & $-6,895$ & $-11,532$ & \multirow{6}{*}{3.160} & \multirow{6}{*}{0.489} & \multirow{6}{*}{2.101} & \multirow{6}{*}{0.817} & \multirow{6}{*}{$\begin{array}{c}\text { not } \\
\text { rejected } \\
H_{0}\end{array}$} \\
\hline & $-6,895$ & 63,335 & $-7,188$ & & & & & \\
\hline & $-11,532$ & $-7,188$ & 65,434 & & & & & \\
\hline \multirow{3}{*}{$\begin{array}{c}\text { Experimental } \\
\text { Class }\end{array}$} & {$[63,610$} & $-25,325$ & $-3,541$ & & & & & \\
\hline & $-25,325$ & 64,825 & 16,589 & & & & & \\
\hline & $-3,541$ & 16,589 & 63,870 & & & & & \\
\hline
\end{tabular}


Table 5. Summary of average research data

\begin{tabular}{lccc}
\hline \multicolumn{1}{c}{ Dependent Variable } & \multicolumn{2}{c}{ Class } & \multirow{2}{*}{ Total Average } \\
\cline { 2 - 3 } & Control & Experimental & 69.54 \\
Mathematics Abstraction $\left(Y_{1}\right)$ & 63.15 & 77.09 & 69.54 \\
Motivation $\left(Y_{2}\right)$ & 79.85 & 89.41 & 84.23 \\
Independence $\left(Y_{3}\right)$ & 76.08 & 85.18 & 80.25 \\
\hline
\end{tabular}

Table 6. Summary of multivariate $T^{2}$ test of research data

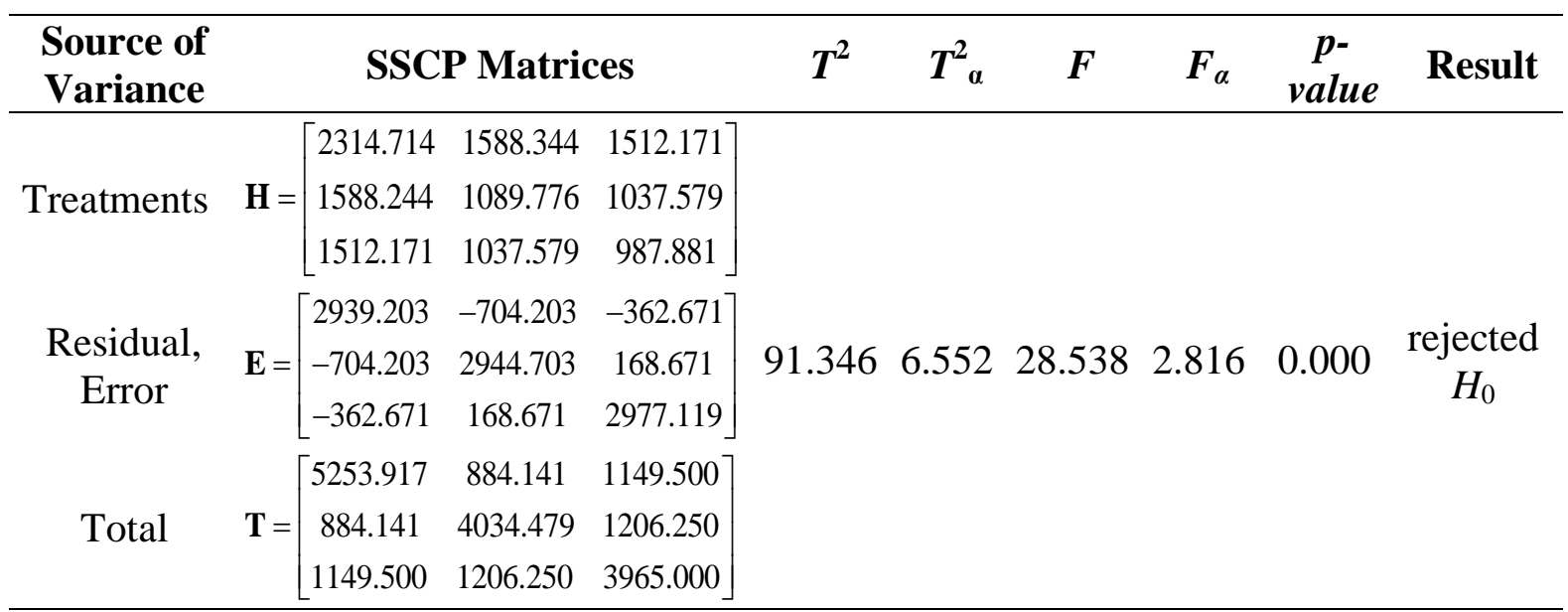

On the basis of multivariate test through SPSS, Pillai's Trace test resulted in $F=$ 28.538 with $p=0.000$; Wilk's Lambda test resulted in $F=28.538$ with $p=0.000$; Hotelling's Trace produced $F=28.538$ with $p=0,000$; and Roy's Largest Root test produced $F=28.538$ with $p=0.000$. All tests constructed $p<\alpha=0.05$, and hence, $H_{0}$ was rejected.

This research focused more on Hotelling's $T^{2}$ test statistics. The summary of analysis is presented in Table 6 . In reference to results of analysis, test statistics of $T^{2}>T_{\alpha}^{2}$ was constructed $\left(T^{2}=91.346\right.$ and $\left.T_{\alpha}^{2}=6,552\right)$. This was supported by $p$-value $<\alpha=0.05$. Therefore, with significance level of $5 \%, H_{0}$ was rejected. This indicated different effects of conventional learning and learning using Mathematica software on students' mathematical abstraction, motivation, and independence in learning analytic geometry with $\alpha=0.05$. In order to find out the differences, further test was carried out using univariate $t$ test on each dependent variable and the summary of analysis is presented in Table 7.

Table 7. Summary of univariate $t$ test of research data

\begin{tabular}{|c|c|c|c|c|c|c|c|}
\hline $\begin{array}{c}\text { Dependent } \\
\text { Variable }\end{array}$ & $T$ & $d f$ & $t_{a}$ & $F$ & $F_{\alpha}$ & p-value & Result \\
\hline $\begin{array}{c}\text { Mathematical } \\
\text { Abstraction }\left(Y_{1}\right)\end{array}$ & 6.019 & 46 & $\begin{array}{c}\text { Lower }=-2.013 \\
\text { Upper }=2.013\end{array}$ & 36.226 & 4.052 & 0.000 & rejected $H_{0}$ \\
\hline Motivation $\left(Y_{2}\right)$ & $\begin{array}{c}- \\
4.126\end{array}$ & 46 & $\begin{array}{c}\text { Lower }=-2.013 \\
\text { Upper }=2.013\end{array}$ & 17.024 & 4.052 & 0.000 & rejected $H_{0}$ \\
\hline $\begin{array}{c}\text { Independence } \\
\qquad\left(Y_{3}\right)\end{array}$ & $\begin{array}{c}- \\
3.977\end{array}$ & 46 & $\begin{array}{c}\text { Lower }=-2.013 \\
\text { Upper }=2.013\end{array}$ & 15.264 & 4.052 & 0.000 & rejected $H_{0}$ \\
\hline
\end{tabular}


Based on the results of further test on each dependent variable, test statistics of $t<$ $t_{1-(\alpha / 2)}$ was constructed, and this resulted in $t \in D K$. In addition, test statistics of $F>F_{\alpha}$ was obtained, and this constructed $F \in D K$. This was also proven by $p$-value $<\alpha=0.05$. In conclusion, $H_{0}$ was rejected in each dependent variable with the significance level of $5 \%$. To derive conclusion related to the different effects, Table 5 needs to be observed, particularly on the average of compared cells. With the significance level of 5\%, we can conclude that: 1) learning using mathematica software $\left(\bar{Y}_{1.2}=77.09\right)$ was more effective in improving students' mathematical abstraction than conventional learning $\left(\bar{Y}_{1.1}=63.15\right)$ was in analytic geometry subject; 2) learning using mathematica software $\left(\bar{Y}_{2.2}=89.41\right)$ was more effective in improving students' motivation on learning than conventional learning $\left(\bar{Y}_{2.1}=79.85\right)$ was in analytic geometry subject; and 3) learning using mathematica software $\left(\bar{Y}_{3.2}=85.18\right)$ was more effective in improving students' independence than conventional learning $\left(\bar{Y}_{3.1}=76.08\right)$ was in analytic geometry subject.

\subsection{Discussion}

Thinking process is an activity occurring in human's brain (Muhtarom, Murtianto $\&$ Sutrisno, 2017). The use of software in learning mathematics in classroom has to be related to portion and conformity level with learning objections. This is for the use of software can influence students' mathematical abstraction, motivation and independence. One of software well-known for mathematics learning, particularly in analytic geometry subject, is Mathematica. No one can deny the benefits of this software. Mathematica software is one of today's latest software and this statement is supported by various researches carried out by Gocheva (2009) and Malinova (2010). Malinova (2010) stated that Mathematica software is highly effective for learning mathematics at the level of university which examines concept and the relation with other mathematical concepts or implementations with technology. Beside that cognitive regulation variable has contributed a greater influence on cognitive variable, than that of cognitive knowledge variable (Kapustina et al., 2015; Pantiwati \& Husamah, 2017), indicating that visualization concepts of analytic geometry would be easier when presented using this software. With the use of mathematical software that displays a variety of visualizations and forms of modeling real geometry it will automatically increase student motivation in learning mathematics. With good learning motivation this will have an impact on student independence. Simultaneously that mathematical software has a positive impact on mathematical abstraction abilities, motivation and independence of students' mathematics learning.

Abstraction ability is defined as a process of depicting a particular situation into a thinkable concept through a process of construction. The thinkable concept can later be used in more complicated and complex level of thinking. Motivation in mathematics education is important for it provides energy in learning which can be adapted to bridge. Motivation related to anxiety and need for achievement (Rachvelishvili, 2017), which reflects the manifestation of the behavior, attitudes, and activities of an individual. Thus, mathematics learning using Mathematica software requires certain motivation to change behavior and attitude through a process of learning, and this is expected to put an effect on the students' independence. According to Listyani (2006), a great number of software that can be used by mathematics pre-service teachers in learning requires them to skillfully utilize software they plan to choose. Mathematical software makes it easy to visualize analytic geometry concepts, with varied visualizations produced by mathematical software that will familiarize students in the process of mathematical abstraction. Hence, learning 
analytic geometry using Mathematica Software is more effective in improving students' mathematical abstraction ability, motivation, and learning independence than conventional learning.

\section{CONCLUSION}

Learning using Mathematica software puts an effect on better mathematic abstraction of students compared to conventional learning in analytic geometry subject, learning using Mathematica software gives more motivation to students for studying compared to conventional learning in Analytic Geometry subject and learning using Mathematica software is more effective in improving students's learning independence compared to conventional learning in Analytic Geometry subject.

\section{REFERENCES}

Budiyono (2003). Educational research methodology. Surakarta: Sebelas Maret University Press.

Gocheva (2009). Introduction into system mathematica. Bulgaria: Express Gabrovo.

Hannula, M. S. (2006). Motivation in mathematics: Goals reflected in emotions. Educational studies in mathematics, 63(2), 165-178.

Kapustina, T. V., Popyrin, A. V., \& Savina, L. N. (2015). Computer support of interdisciplinary communication of analytic geometry and algebra. International Electronic Journal of Mathematics Education, 10(3), 177-187.

Listyani, E. (2006). Efforts to increase achievement and independence learning differential calculus with mathematica software on mathematics study program students FMIPA UNY. Yogyakarta: FMIPA UNY.

Malinova, A. (2010). Teaching university-level mathematics using mathematica. Bulgaria: Plovdiv.

Muhtarom, M., Juniati, D., \& Siswono, T. Y. E. (2017a). Exploring beliefs in a problemsolving process of prospective teachers' with high mathematical ability. Global Journal of Engineering Education, 19(2), 130-136.

Muhtarom, M., Juniati, D., \& Siswono, T. Y. (2017b). Consistency and inconsistency of prospective teachers' beliefs in mathematics, teaching, learning and problem solving. In AIP Conference Proceedings, 1868(1), 050014.

Muhtarom, M., Murtianto, Y. H., \& Sutrisno, S. (2017). Thinking process of students with high-mathematics ability (A study on QSR NVivo 11-assisted data analysis). International Journal of Applied Engineering Research, 12(17), 6934-6940.

Nizaruddin, N., Muhtarom, M., \& Sugiyanti, S. (2017). Improving students' problemsolving ability in mathematics through game-based learning activities. World Transaction on Engineering and Technolgy Eduction, 15(2), 102-107.

Pintrich, P. R. (2003). A motivational science perspective on the role of student motivation in learning and teaching contexts. Journal of educational Psychology, 95(4), 667686. 
Pantiwati, Y., \& Husamah, H. (2017). Self and peer assessments in active learning model to increase metacognitive awareness and cognitive abilities. International Journal of Instruction, 10(4), 185-202.

Rachvelishvili, N. (2017). Achievement motivation toward learning english language in modern educational context of georgia. Problems of Education in the 21st Century, 75(4), 366-374.

Rencher, A. C. (2002). Methods of multivariate analysis. Canada: John Willey \& Sons. Inc. Publications.

Sunandar, S., Murtianto, Y. H., \& Sutrisno, S. (2015). Development of teaching-assisted software mathematica in developing student mathematics representation ability. Semarang: Universitas PGRI Semarang.

Vosler, D. (2009). Exploring analytic geometry with mathematica. Boston: Academic Press. 